\title{
Editorial for Issue 1, Jan 2016 title of the editorial 2016 : A year for JCCS Editorial changes and CCN3 KO mice at ICCNS
}

\author{
Bernard Perbal $^{1,2}$
}

Received: 1 February 2016 / Accepted: 1 February 2016/Published online: 23 February 2016

(C) The International CCN Society 2016

\begin{abstract}
The year 2016 will see significant improvements for the Journal of Cell Communication and Signaling with the earning of an official Impact Factor and the merger of Springer Science + Business Media and part of Macmillan Sciences and Education. It will also be an important year for the International CCN Society (ICCNS) with the nomination of a new Scientific Board and reinforcement of interactions with other major scientific societies interested in various aspects of Cell Signaling. Starting this year the ICCNS will become an official provider of CCN3 knock out mice to ICCNS members. This first step in opening up access to certified reagents as a service for our $\mathrm{CCN}$ scientific community is part of our intention and efforts to attain the highest degree of assistance and enabler of scientific cooperation and communication in Science Communication.
\end{abstract}

At the dawn of 2016, it is my great pleasure to wish all our readers an excellent new year, full of familial satisfaction and professional success.

The year 2016 will be an important one for the Journal of Cell Communication and Signaling as it will be assigned its first official impact factor (IF) through the indexing of its contents by Thomson Reuter. Earning of the IF is a major step in the life of a scientific journal as I had discussed in a previous editorial (Perbal 2015).

Bernard Perbal

bperbal@gmail.com

Sources et Méthodologie du Droit Economique. GREDEG-CREDECO CNRS UMR 7321, Université de Nice-Sophia Antipolis, Nice, France

2 International CCN Society, Nice, France
It also coincides with the recent merger of Springer Science + Business Media and part of Macmillan Science and Education (including the nature Publishing Group).

As a result of this merger, responsibility for the Journal of Cell Communication has been transferred from Thijs van Vlijmen to Meran Owen. Thijs had been assigned JCCS 7 years ago, shortly after Peter Butler and I had agreed to create JCCS as the continuation of the former Cell Communication and Signaling that I had created at BMC. During these past 7 years, Thijs supported our commitment and efforts to improve the scientific quality and audience of the journal.

Meran Owen holds a Ph.D. in Genetics and spent many years as a researcher in Canada and in the United Kingdom. Meran worked with Elsevier as an Editor of Trends in Biotechnology, part of the Business Development group and as Senior Publishing Editor in Biomedicine/Life Sciences Division at Springer for 9 years. We trust that Meran Owen's qualifications and his past experience in publishing are assets that should prove very precious for the scientific future of JCCS.

Let me take this opportunity to express my sincerest thanks to those who shared with me the responsibility of bringing JCCS to the attention of the scientific community as an essential journal in the field of cell communication and signaling, in spite of the very tough competition from other major publishing groups who all created journals on the same topic after our initial creation of CCS .

\section{Bucket list for 2016}

In addition to increasing the net number of articles submitted to the main sections of JCCS (Pathology and Translational Research, Molecular Signaling and Reviews), our goals for 
2016 also include an increase in communications submitted either as Bits and Bytes or commentaries.

Although our section editors spend quite a significant amount of time to convince colleagues to submit comments it seems that these sections do not attract many authors, even though they are also indexed on PubMed as original manuscripts as soon as they are accepted.

This section could be much more lively, as an open forum, with comments presented by senior and young researchers on any field of interest. These could then trigger discussions and exchange of viewpoints about new trends, techniques, or scientific progress.

Getting people to commit themselves to editing a special issue of JCCS on a topic of their choice would fullfil another wish that we would like to see come true in 2016.

Solicited thematic issues can cover any field of interest for the $\mathrm{CCN}$ and signaling scientific communities. Information on these can be obtained by contacting me directly.

\section{The 8th International Workhop on the $\mathrm{CCN}$ family of genes}

In addition to regular research manuscripts and reviews, this first issue of 2016 also contains a report on the 8th International Workshop on the CCN family which was held from November $3 \_8$ in Nice and includes the abstracts of the talks that were presented.

The meeting was a resounding success voiced by all who attended. We were honored to host two special guests.

Judith Campisi received the 2015 ICCNS Springer award for her achievements in the field of cancer research and senescence. Robert Baxter, a previous ICCNS-Springer Awardee, presented a special conference on IGFBP3 and cancer.

We are very grateful to both of these talented colleagues for staying during the whole time of the meeting, thereby providing a unique opportunity to all those who wanted to meet them and discuss various aspects in their presentations.

Everyone agreed that the quality of the presentations given at the meeting is attaining a very high standard and is greatly contributing to the scientific recognition of the $\mathrm{CCN}$ field and one that is very productive. The place and dates of the next meeting will be announced in these pages and on the ICCNS web site.

\section{ICCNS scientific board}

The Scientific Board of the International CCN Society has been renewed this year, as the mandate of M. Takigawa ended in 2015. Lester Lau accepted my invitation to become the President of the Scientific Board in addition to his present position as head of the ICCNS Council.

In an effort to reinforce and create productive contacts for the ICCNS with other societies with whom we share scientific interest, a few colleagues have accepted our invitation to become the « liaison » with other societies, in order to foster dynamic exchanges and work on possible participations in each other's meetings. The new composition of the ICCNS advisory scientific board will be published shortly on the ICCNS web site.

In conclusion, we expect 2016 to be a banner year for progress and the exchange of new ideas and valuable reagents. Along this line I have worked out a special agreement with the Japanese colleagues with whom I published on the isolation and partial study of the only true CCN3 knockout mouse model available as of today (Shimoyama et al. 2010; Leask 2010). The ICCNS is now allowed to provide the CCN3 KO mice to all ICCNS members who will request them. Details regarding the procedure will be published on the ICCNS website shortly. We do hope that this first step in providing access to a certified reagent will signal the beginning of a wider sharing of reagents, something we had proposed several years ago with J. Castellot on the ICCNS web site, and a goal discussed at each International Workshop over many years.

With my renewed warmest wishes to all of you,

Bernard Perbal

Editor in Chief

\section{References}

Leask A (2010) It's a knockout: CCN3 suppresses neointimal thickening. J Cell Commun Signal 4(2):109-110. doi:10.1007/s12079-0100086-y

Perbal B (2015) What kind of a life for a scientific journal? J Cell Commun Signal 9(3):201-206. doi:10.1007/s12079-015-0306-6

Shimoyama T, Hiraoka S, Takemoto M, Koshizaka M, Tokuyama H, Tokuyama T, Watanabe A, Fujimoto M, Kawamura H, Sato S, Tsurutani Y, Saito Y, Perbal B, Koseki H, Yokote K (2010) CCN3 inhibits neointimal hyperplasia through modulation of smooth muscle cell growth and migration. Arterioscler Thromb Vasc Biol 30(4): 675-682. doi:10.1161/ATVBAHA.110.203356 